\title{
上吹きランスによるガスジェットの低融点金属浴への 貫入深さの予測
}

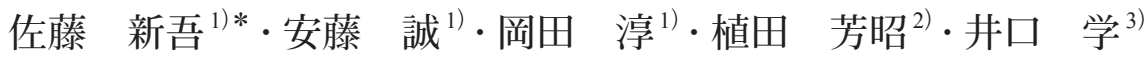

Prediction of Plunging Depth Induced by Top Lance Gas Blowing onto a Low-melting-point Metal Bath

Shingo Sato, Makoto Ando, Jun OKada, Yoshiaki UedA and Manabu Iguchi

Synopsis : Experimental and numerical investigations were carried out to understand cavity formation on a water and a low-melting-point metal bath induced by gas blowing from a top lance set in the near field of the bath surface. A cavity formation behavior was classified by the critical gas velocity of the droplet formation. The depth of the cavity formed in the near field of the gas jet was reasonably predicted by numerical simulation. An empirical equation was newly proposed for the cavity depth as a function of a modified Froude number.

Key words: cavity depth; cold model; low-melting-point metal; wood's metal; numerical simulation; modified froude number.

\section{1. 緒言}

転炉における鉄鋼精鍊プロセスでは, 脱炭等のため上吹 きランスから高流量の酸素ジェットを鋼浴表面に吹き付け ている。この強い酸素ジェットにより, 鋼浴表面には等み ができるとともに, 浴面は激しく遥動し, スピッティング やスプラッシュ等が発生する。この浴面遥動によって生成 される液滴群は, ダストとなってメタルの損失をもたらす だけではなく, 上吹きランスや炉壁等に付着して多くの不 都合につながることから, その生成打よび飛散挙動の解明 が望まれている ${ }^{1-21)}$ 。

一般的に，上吹きランスが浴表面に近いほど浴面摇動は 激しくなり，液滴飛散量が多くなるだけではなく，上吹き ランスへの地金の付着量も多くなり操業上好ましくない。 そのため, 実操業では上吹きランス下端から浴表面までの 距離 $h_{\mathrm{n}}$ をランスの内径 $d_{\mathrm{ni}}$ で除した值は打よそ10以上の範 囲に設定されている ${ }^{16)}$ 。すなわち, このような設置位置に よって浴表面の䚓拌力は弱くなり, 大きなエネルギー損失 が生じることになる。よって, 何らかの方法で窪みの形成 に起因する浴表面の摇動と液滴飛散を抑えることができれ ば，上吹きランスを浴表面に近い位置に設置して効率の良 い操業が可能となる。

これまで，上吹きランスからのガス吹き付けによる窪み 形成と浴表面の摇動については, 上記操業条件を参考にし て, ランス下端から浴表面までの距離とランス内径との比
が 10 以上の範囲で多くのモデル実験が行われてきた。こ のようなランス位置が高い場合の窪み深さ $h_{\mathrm{j}}$ は, 後述の 運動量数 $\mathrm{M}_{\mathrm{m}}$ で整理できることが分かっている ${ }^{10)}$ 。この区 間 (Far field) では, 噴流の中心軸上の速度がほぼランス出 口からの距離 $x$ に反比例して減少し, 噴流幅は $x$ に比例し て大きくなる。ところが, ランス近傍ではこの関係式は成 立せず, 運動量数の関数として提案されている従来の実験 式は適用できない。本研究では, 上吹きランスによる強䚓 拌を得るため, エネルギー損失が比較的小さい領域である $h_{\mathrm{n}} / d_{\mathrm{ni}}$ が 10 よりも十分小さい場合（Near field）に着目し，ラ ンス出口における噴流の特性量ではなく, 浴表面における 特性量に着目して, 嵀み形成と浴表面の摇動, ならびに液 滴の発生について, モデル実験と数值計算の両面から解明 を行うことを試みた。

転炉内の浴内流動場の現象は, 溶鋼と水の動粘度がほぼ 等しいことを利用して水モデル実験により評価されるこ とが多い ${ }^{1-5)}$ 。液体として水の他にアルコール類やグリセ リン水溶液, 四塩化炭素などを用いた従来のコールドモデ ル実験 ${ }^{6}$ によれば, スピッティングやスプラッシュ発生の 源となる窪みの形成については, 液体の表面張力と粘度の 影響は小さいといわれている7。ただし，これらのコール ドモデル実験においては, 液体の粘度は大きく変化させ ることができるが, 表面張力については水の表面張力の $73 \mathrm{mN} / \mathrm{m}$ よりも約 $30 \%$ 小さくできる程度である。したがっ て, 洼みの形成に関する表面張力の影響に関しては, 溶鋼

2018年8月10日受付２018年9月13日受理（Received on Aug. 10, 2018 ; Accepted on Sep. 13, 2018)

1）JFEスチール (株) スチール研究所 (Steel Research Laboratory, JFE Steel Corporation, 1-1 Minamiwatarida-cho Kawasaki-ku Kawasaki Kanagawa 210-0855)

2) 攝南大学理工学部 (Faculty of Science and Engineering, Setsunan University)

3) 北海道大学名誉教授 (Professor Emeritus, Hokkaido University)

* Corresponding author : E-mail : shing-sato@jfe-steel.co.jp

DOI : https://doi.org/10.2355/tetsutohagane.TETSU-2018-125 
と水とで表面張力が約 20 倍も異なることから，コールドモ デル実験の結果がそのまま実機に適用できるとは限らな い。また, 表面張力の影響を受ける液滴の大きさや形状に ついても, 水モデルで得られた結果とは異なる可能性が高 い。スピッティングやスプラッシュについては過去多くの 調查がなされているが ${ }^{5,8-12)}$ ，溶融金属の洼みに関する研究 は, $h_{\mathrm{n}} / d_{\mathrm{ni}}$ が約 10 よりも十分大きい場合についてしか見ら れない ${ }^{13-16)}$ 。なお，数值解析に関しても，水を対象とした ものがほとんどであり ${ }^{17-19)}$ ，溶融金属を対象とした解析モ デルは，近年研究が進みつつあるが，まだ数が少ないのが 現状である ${ }^{20,211}$ 。

本報では, 浴表面近傍に設置した上吹きランスからのガ 又噴流の吹き付けによる自由界面挙動に及ぼす液体の物性 值の影響を解明することを目的に，ランス出口と浴表面が 近い条件において，低融点金属であるウッドメタルと水を 用いた実験に加えて数值解析を実施し，まず液面の䇠み深 さ（以下，洼みの貫入深さと呼ぶ）について調査した結果 について報告する。

\section{2. コールドモデル実験の装置と方法}

\section{$2 \cdot 1$ 低融点金属を用いたコールドモデル実験}

Fig.1 に実験装置の模式図を示す。上吹きランスの内 径 $\left(d_{\mathrm{ni}}=10 \mathrm{~mm}\right)$ に比べて十分大きな円筒容器（直径 $D=$ $200 \mathrm{~mm}$ ）に，低融点金属であるウッドメタル（密度 $\rho_{\mathrm{L}}=$ $9560 \mathrm{~kg} / \mathrm{m}^{3}$, 動粘度 $v_{\mathrm{L}}=0.341 \times 10^{-6} \mathrm{~m}^{2} / \mathrm{s}$, 表面張力 $\sigma_{\mathrm{L}}=$ $431 \mathrm{mN} / \mathrm{m}$, 融点 $\left.73^{\circ} \mathrm{C}\right)^{22)}$ を浴深 $H_{\mathrm{L}}=100 \mathrm{~mm}$ まで満たして おき, 容器下部からヒーターで温め溶融させ, 実験中に温 度がほぼ一定に保つようにヒーターの出力を調整した（浴 温 $\left.105^{\circ} \mathrm{C}\right)$ 。実験は大気開放環境下にて行うため, 浴表面に は酸化膜（スカム）が形成されるが, 各実験の前にその都 度除去した。上吹き鉛直ランスは, 液面上 $h_{\mathrm{n}}=8,17 \mathrm{~mm}$ $\left(h_{\mathrm{n}} / d_{\mathrm{ni}}=0.8,1.7\right)$ の位置に下向きに設置した。空気流量を $Q_{\mathrm{g}}=44.6$ から $129 \mathrm{~L} / \mathrm{min}$ の間で変化させ, 液面に向けて垂 直に吹き付けた。ランス出口でのガスジェット吐出速度 は, 空気の密度を一定とすると $v_{\mathrm{n}}=9.46 \sim 27.4 \mathrm{~m} / \mathrm{s}$ となる。 空気の温度は $27^{\circ} \mathrm{C}(=300 \mathrm{~K})$, 密度は $\rho_{\mathrm{g}}=1.17 \mathrm{~kg} / \mathrm{m}^{3}$, 動 粘度は $v_{\mathrm{g}}=15.29 \times 10^{-6} \mathrm{~m}^{2} / \mathrm{s}$ である。

ガスジェットの衝突によって浴表面上に形成される滗 みの深さの最大值，すなわち貫入深さ $h_{\mathrm{j}}$ を測定した。測定 は，低融点金属が不透明であるため, 低融点金属内に熱電 対を浸漬させる方法を採用した。以下に測定方法の詳細を 示す。始めに熱電対の先端を気相中に存在するように設置 し，ガス吹き付け後，熱電対の先端を徐々に降下させた。 熱電対の先端が浴表面よりも上方にあると指示温度は浴 温に比べて低いが，低融点金属内に侵入した瞬間に浴温の $105^{\circ} \mathrm{C}$ を示す。このときの熱電対位置とガス吹込み前の初 期静止浴表面との距離を貫入深さ $h_{\mathrm{j}}$ とした。ガス吹き付け
中の浴表面は時間変動しており，時間変動の影響を小さく するために, 測定は各実験条件につき 10 回実施し, その平 均值を採用した。なお，各条件での測定值のばらつきは， 平均值に対し $\pm 20 \%$ 程度であった。

\section{$2 \cdot 2$ 水を用いたコールドモデル実験}

実験装置にはFig.1に示した低融点金属での装置と同 じものを用いた。低融点金属の場合と同様に上吹きラン スの内径は $d_{\mathrm{ni}}=10 \mathrm{~mm}$, 透明アクリル製円筒容器の内径 は $D=200 \mathrm{~mm}$ である。温度 $27^{\circ} \mathrm{C} （=300 \mathrm{~K} ）$ の水を円筒 容器内に浴深 $H_{\mathrm{L}}=100 \mathrm{~mm}$ まで満たしておき, 上吹き鉛 直ランスから $27^{\circ} \mathrm{C}$ の空気を吹き付けた。水の密度は $\rho_{\mathrm{L}}=$ $996.5 \mathrm{~kg} / \mathrm{m}^{3}$, 動粘度は $v_{\mathrm{L}}=0.854 \times 10^{-6} \mathrm{~m}^{2} / \mathrm{s}$, 表面張力は $\sigma_{\mathrm{L}}$ $=71.7 \mathrm{mN} / \mathrm{m}$ である。上吹きランスの出口から初期静止液 面までの距離は低融点金属の場合と同様に $h_{\mathrm{n}}=8,17 \mathrm{~mm}$, 空気流量は $Q_{\mathrm{g}}=17.6 \sim 129 \mathrm{~L} / \mathrm{min}$ とした。貫入深さ $h_{\mathrm{j}}$ は浴 の側面からスチールカメラを用いて測定した。この場合も 各実験条件につき 10 回測定を行い，先の平均值を採用し た。

本研究で用いた 3 種類の流体の物性值をまとめて Table 1 に示す。水とウッドメタルの表面張力は, 約6倍異なって いる。

\section{3. 数值解析方法}

数值解析には, 有限体積法に基づくソルバーである STAR-CCM+ ver.11.02を使用した。気相, 液相ともに非圧

Table 1. Physical properties of fluids.

\begin{tabular}{ccccc}
\hline Fluid & $\begin{array}{c}\text { Temperature } \\
{\left[{ }^{\circ} \mathrm{C}\right]}\end{array}$ & $\begin{array}{c}\text { Density } \\
{\left[\mathrm{kg} / \mathrm{m}^{3}\right]}\end{array}$ & $\begin{array}{c}\text { Kinematic } \\
\text { viscosity }\left[\mathrm{m}^{2} / \mathrm{s}\right]\end{array}$ & $\begin{array}{c}\text { Surface tension } \\
{[\mathrm{mN} / \mathrm{m}]}\end{array}$ \\
\hline Water & 27 & 997 & $0.854 \times 10^{-6}$ & 72 \\
Wood's metal $^{22)}$ & 105 & 9560 & $0.341 \times 10^{-6}$ & 431 \\
Air & 27 & 1.17 & $15.29 \times 10^{-6}$ & - \\
\hline
\end{tabular}

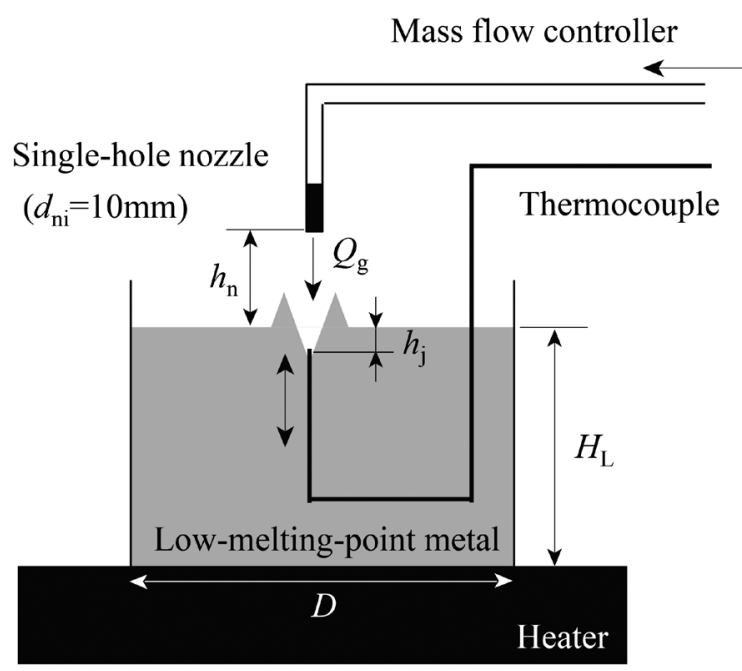

Fig. 1. Schematic of experimental apparatus. 
縮の Navier-Stokes 方程式，連続の式を支配方程式とし，自 由界面解析にVOF 法 ${ }^{32)}$, 乱流モデルに Realizable $\mathrm{k}-\varepsilon^{33)}$ を採 用した。時間進行については 1 次精度陰解法, 対流項につ いては2次精度風上法を採用した。低融点金属浴打よび空 気の温度はそれぞれ $105^{\circ} \mathrm{C}(=378 \mathrm{~K}), 27^{\circ} \mathrm{C}(=300 \mathrm{~K})$ と し, 容器の壁面は断熱条件とした。

数值解析モデルについては, 前章の実験装置と同様の形 状にて数值解析を行った。Fig.2 に格子形状を示す。解析格 子数は約 100 万であり, ランス出口近傍や気液界面近傍に おいて格子密度が高くなるように配置した。上吹きランス の出口から初期静止液面までの距離は，実験と同様に $h_{\mathrm{n}}=$ $8,17 \mathrm{~mm}$, 空気流量は $Q_{\mathrm{g}}=45 \sim 250 \mathrm{~L} / \mathrm{min}$ とした。これは, 実験条件を含む, やや広い流量範囲を対象としている。数 值解析における貫入深さ $h_{\mathrm{j}}$ は, 容器中心軸上において液相 の体積分率が 0.5 となる等值面を抽出し, 所定時間経過後 (本研究では第 1 キャビティ形成後) の貫入深さの時間平均 值と定義した。

上吹きランスによる噴流挙動とそれにより変形する液体
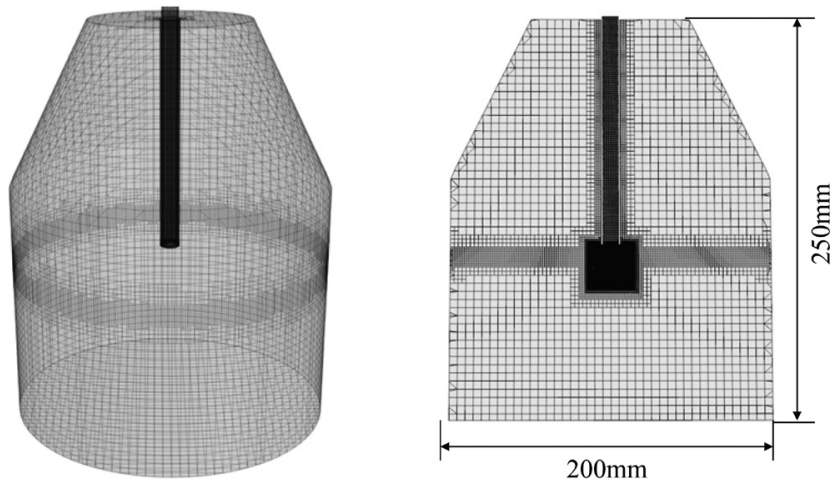

Fig. 2. Schematic of simulation model.
の動的挙動を効率的に解析する手法として「2段階数值解 析手法」が提案 ${ }^{19)}$ されているが，今回の条件では上吹きラ ンスによる噴流の速度が小さいため, CFL 条件 (クーラン 条件）を満たす時間ステップ $\Delta t$ は大きくとることができ る。よって, 今回のモデルでは上吹きランスによる噴流挙 動とそれにより変形する液体表面の動的挙動を同時に解析 した。

\section{4. 実験結果ならびに数値解析結果}

\section{$4 \cdot 1$ 貫入深さ $h_{\mathrm{j}}$ とガス流量 $Q_{\mathrm{g}}$ との関係に関する従来知見}

これまでに，鉛直上吹きランスによるガス吹き付けに よって形成される浴表面の窪みの変動と，それに関連する スピッティング現象などを整理している研究はいくつか 見られる ${ }^{23-25)}$ 。徳田は, 水モデル実験に基づき鉛直上吹き ランスによるガス吹き付けによって形成される浴表面の 窪みと，それに関連するスピッティング現象などを整理し ている ${ }^{23)}$ 。Fig.3に徳田による図表を一部修正して示す。上 吹きランス内径 $d_{\mathrm{ni}}$ とランス高さ $h_{\mathrm{n}}$ を一定にして空気流量 $Q_{\mathrm{g}}$ を大きくしていくと，等みは徐々に深くなっていき（ス テージ A)，やがて䇠みの周辺の液体が盛り上がる（ステー ジ B)。この盛り上がりは, 篗み表面に沿って大気中へ出て いく空気が液面に及ぼすせん断力によって生じる。もう少 し空気流量 $Q_{\mathrm{g}}$ を大きくすると, 深くなった等みの底部近傍 の空気が気泡のようになり，やがて気柱ができる（ステー ジC)。周辺の盛り上がり部は，より強くなったせん断力に よって引きちぎられ，多くの液滴が大気中へ放出される。 さらに空気流量 $Q_{\mathrm{g}}$ を増加させると空気噴流は液中にその まま侵入し，その先端近傍が気泡となって液中に巻き込ま れるようになる(ステージD)。なお，ステージDはマッハ 数 $\mathrm{M}\left(=v_{\mathrm{n}}{ }^{\prime} / c\right)$ が大きい高速噴流の場合にみられるとして
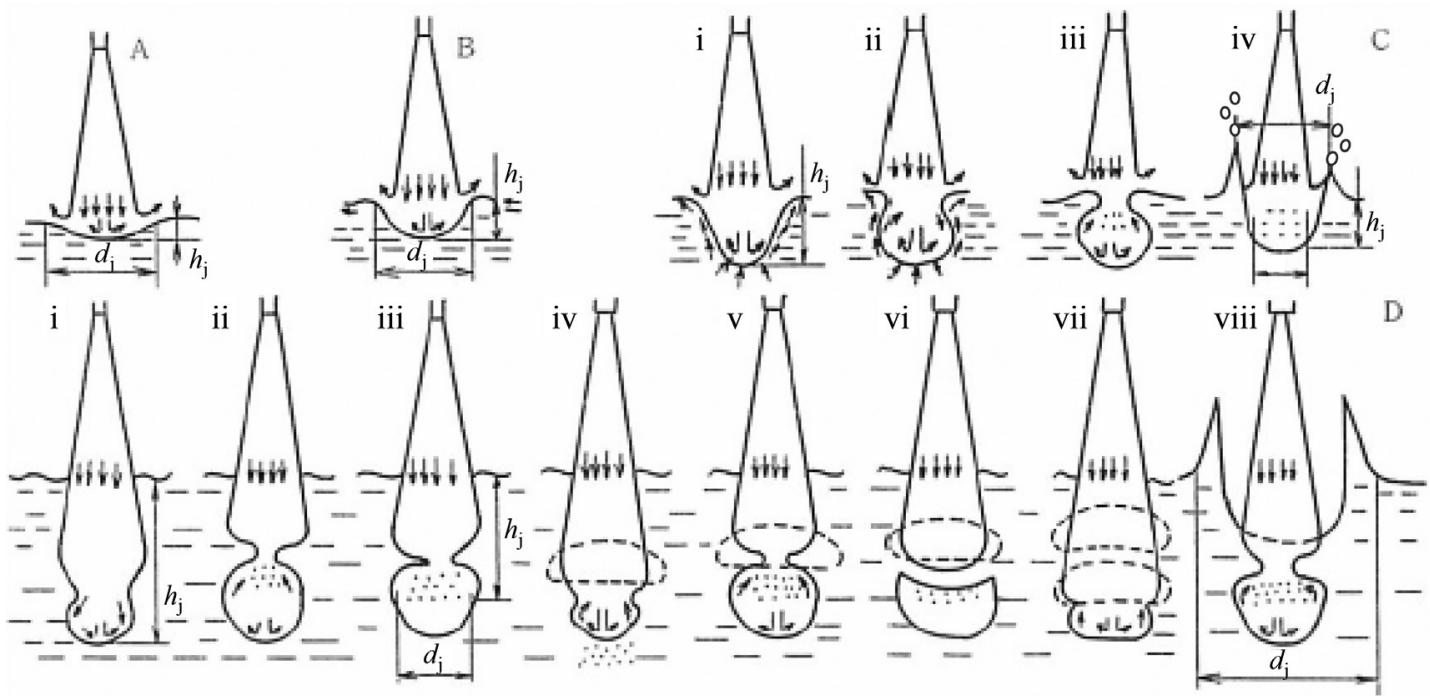

Fig. 3. Relationship between cavity formation and gas flow rate ${ }^{23)}$. 
いる。ここで, $v_{\mathrm{n}}{ }^{\prime}$ は浴表面における噴流の速度 $[\mathrm{m} / \mathrm{s}], \mathrm{c}$ は 音速 $[\mathrm{m} / \mathrm{s}]$ である。本研究では, 第一段階として噴流速度 の比較的小さいステージ $\mathrm{A} \sim \mathrm{C}$ を対象とし, 実駼結果や数 值解析結果を徳田の知見と比較・検証を行った。また, 各 ステージに対し, 貫入深さ $h_{\mathrm{j}}$ の予測式を構築することを試 みるとともに, 各ステージの境界となるガス流量条件につ いても検討を行った。

なお, Fig.3には上吹きジェットによって生じる篗みの 旋回現象は含まれていないが，吹き付け条件によってはス テージCで等みの部分が浴中心軸の周りを旋回することも ある ${ }^{25)}$ 。また，窪みの半径方向への摇動もみられることも あるが，これら現象が貫入深さに及ぼす影響は小さい。

\section{$4 \cdot 2$ 実験結果}

Fig.4に水でのガス噴流の貫入深さ $h_{\mathrm{j}}$ を, Fig.5に低融点 金属でのガス噴流の貫入深さ $h_{\mathrm{j}}$ を示す。まず水の場合に着 目すると，ガス流量 $Q_{\mathrm{g}}$ が大きくなるにつれて貫入深さ $h_{\mathrm{j}}$ は大きくなっている。これは，ガス流量が大きくなると浴 表面に衝突する噴流の慣性力が大きくなるためである。ま た, ランス位置 $h_{\mathrm{n}}$ の影響はほとんど見られなかった。これ

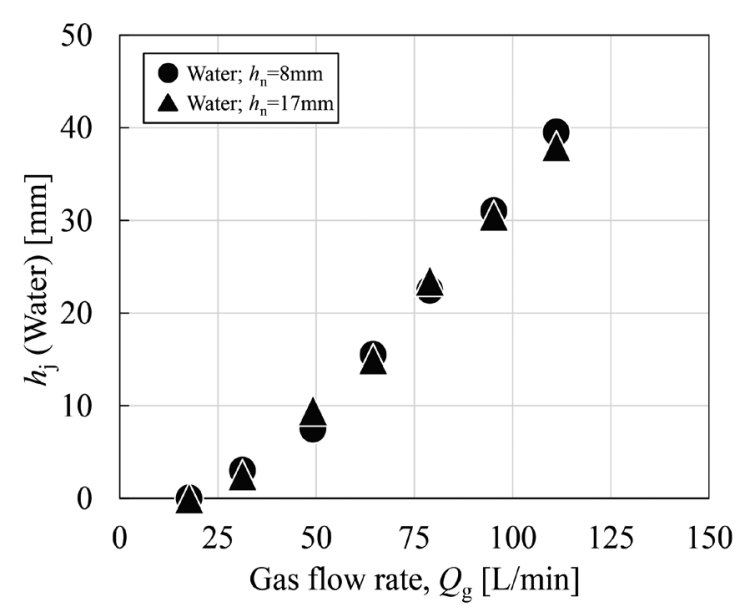

Fig. 4. Measured cavity depth of water.

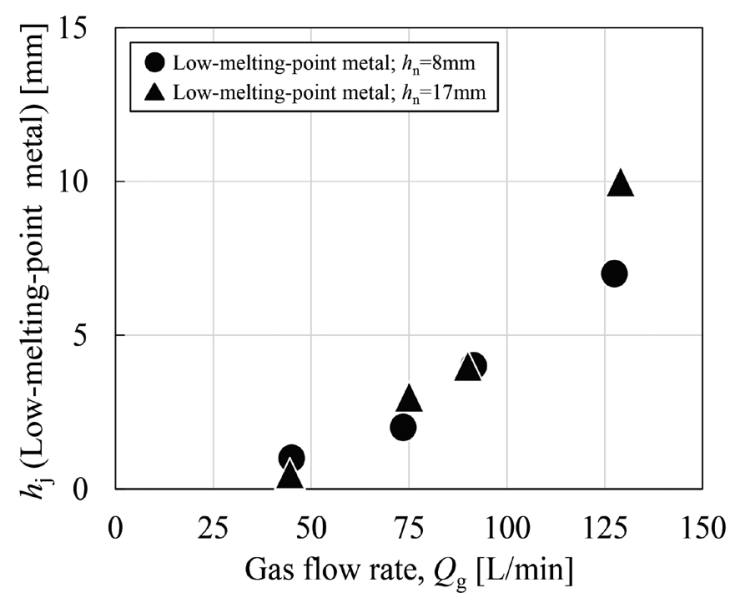

Fig. 5. Measured cavity depth of low-melting-point metal.
は, 本条件での浴表面に衝突する噴流の速度 $v_{\mathrm{n}}{ }^{\prime}$ が，ほとん ど変わらなかったためといえる。Kumagai and Iguchi ${ }^{25)} に よ$ れば，ランス出口に打ける噴流速度 $v_{\mathrm{n}}$ と浴表面に打ける噴 流速度 $v_{\mathrm{n}}{ }^{\prime}$ の間には次の関係があるとしている。

$$
\begin{aligned}
& v_{n}^{\prime}=v_{n} \quad\left(h_{\mathrm{n}} / d_{\mathrm{ni}}<1.26\right) \cdots \\
& =\frac{v_{n}}{0.00523\left(h_{n} / d_{n i}-1.26\right)^{2}+1} \quad\left(1.26 \leqq h_{\mathrm{n}} / d_{\mathrm{ni}}<17.2\right) . \\
& =\frac{v_{n}}{0.167\left(h_{n} / d_{n i}\right)-0.543} \quad\left(17.2 \leqq h_{\mathrm{n}} / d_{\mathrm{ni}}\right) \text {. } \\
& v_{\mathrm{n}}=\frac{4 Q_{\mathrm{g}}}{\pi d_{\mathrm{ni}}{ }^{2}}
\end{aligned}
$$

ここで, $h_{\mathrm{n}}$ はガス吹込み前の浴表面からランスまでの距 離, $Q_{\mathrm{g}}$ はガス流量, $d_{\mathrm{ni}}$ はランス内径である。ランス位置が $h_{\mathrm{n}} / d_{\mathrm{ni}}<1.26$ の領域にある場合には, 浴表面はいわゆるガス 噴流のポテンシャルコア内に存在することになる。本条件 では, $h_{\mathrm{n}} / d_{\mathrm{ni}}$ が $0.8,1.7$ であり, 式 (1) から計算するとほぼ $v_{\mathrm{n}}$ $=v_{\mathrm{n}}{ }^{\prime}$ となる。

Fig.5に示すように, 低融点金属のガス流量 $Q_{\mathrm{g}}=$ $125 \mathrm{~L} / \mathrm{min}$ の条件にて, ランス位置 $h_{\mathrm{n}}$ の違いより, 貫入深さ $h_{\mathrm{j}}$ が異なる結果が得られた。すなわち, 式 (1) から計算さ れるように，浴表面における噴流速度 $v_{\mathrm{n}}$ がほぼ等しいにも 関わらず, $h_{\mathrm{n}}=17 \mathrm{~mm}$ の場合の貫入梁さ $h_{\mathrm{j}}$ が $h_{\mathrm{n}}=8 \mathrm{~mm}$ の 場合より大きくなった。この原因は, 熱電対を用いた測定 精度の問題であると推察される。ガス流量 $Q_{\mathrm{g}}$ を増加させ ることで浴面変動が大きくなり，それにともない貫入深さ $h_{\mathrm{j}}$ の変動も大きくなるが, 熱電対による測定はその変動の 瞬時の値を計測するため, 特に大流量となる条件では測定 精度に課題がある。このため, このような貫入深さ $h_{\mathrm{j}}$ の差 が生じたと考えられる。

一方, $h_{\mathrm{j}}$ はガス流量 $Q_{\mathrm{g}}$ の2 乗に比例して増加しているよ うに見えるが, 水に比べて低融点金属の方が極めて小さ い。密度の大きい低融点金属の方が, 大きな浮力を生み出 し，窪みの形成を抑止するためである。

\section{$4 \cdot 3$ 数值解析結果}

Fig.6に, 空気噴流を吹き付けた際の水浴と低融点金属浴 での貫入深さ $h_{\mathrm{j}}$ の時間履歴をそれぞれ示す。いずれの浴で も空気吹き付け直後の貫入深さが最も大きく, それ以降の 貫入深さは時間ともに減衰していき, やがて定常的な振動 状態に落ち着く様子がみられた。定常的な振動状態におけ る貫入深さの時間平均值を実験結果と比較した。

Fig.7 に, 空気噴流の低融点金属浴への貫入深さ $h_{\mathrm{j}}$ に関す る数值解析結果を実験結果と比較して示す。罒より, 数值 解析結果は実験結果と比較的良く一致していることがわか る。また，本論文には示していないが，水浴への貫入深さ 
$h_{\mathrm{j}}$ についても比較的良い一致が得られた。

Fig.8に数值解析における $90 \mathrm{~L} / \mathrm{min}$ と $250 \mathrm{~L} / \mathrm{min}$ での気液 界面形状の断面困を示す。四より，90 L/minでは浴表面が わずかに等む程度となり，徳田によるステージ Aの挙動を 示している。一方, $250 \mathrm{~L} / \mathrm{min}$ ではステージCのように気柱 形成や液滴飛散を繰り返す現象が見られた。以上のよう に，徳田による浴表面の社み挙動を数值解析でも再現でき たと言える。

\section{5. 考察}

\section{$5 \cdot 1$ 貫入深さ $h_{\mathrm{j}}$ の予測式の導出}

従来，ステージ A〜Dのうち特に液滴の発生に関係の深 いステージ C, Dについては数多くの研究がなされており, 液滴飛散に関する貴重な知見が蓄積されている ${ }^{5,8-12,23)}$ 。し

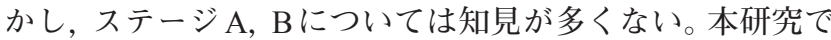

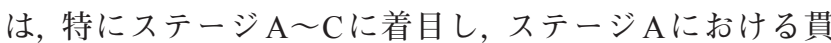
入深さの推定式を構築するとともに，ステージCでの既存

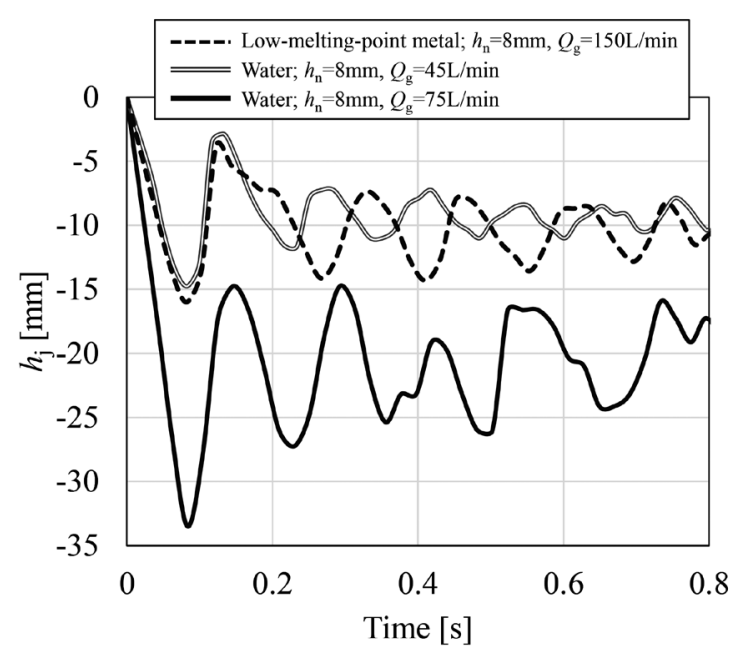

Fig. 6. Time history of cavity depth by simulation.
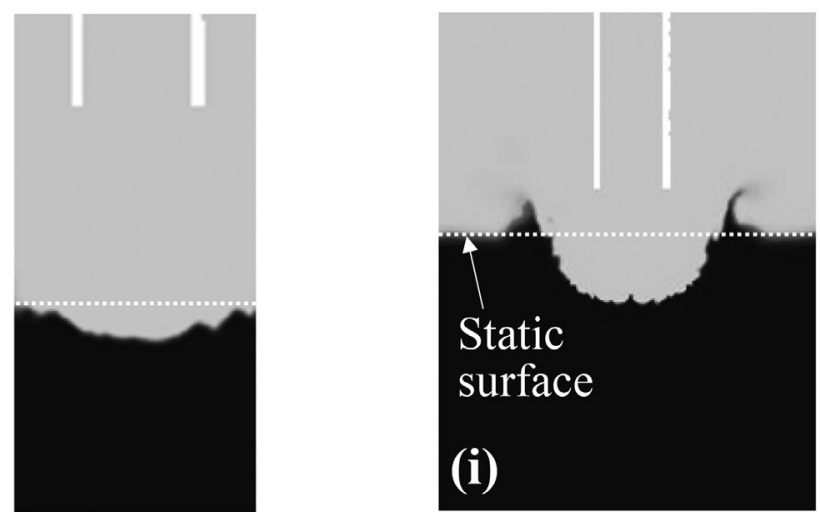

(a) $90 \mathrm{~L} / \mathrm{min}$
の推定式と比較し， $h_{\mathrm{n}} / d_{\mathrm{ni}}$ が小さい場合（Near field）におけ る貫入深さの推定式を検討した。

$5 \cdot 1 \cdot 1$ ステージ A

Fig.3のステージ A に示すように, 窪みは球の一部のよう な形状をしている。浴表面における窪みの直径を $d_{\mathrm{j}}$, 窪み の最大貫入深さを $h_{\mathrm{j}}$ で表す。峙みには気体噴流の慣性力が 下向きに，静水圧による浮力と表面張力による力が上向き に働くので，釣り合いの式は近似的に次の式（3）のように 表される。

$$
\frac{\pi d_{\mathrm{j}}^{2}}{4} \frac{\rho_{\mathrm{g}} v_{\mathrm{n}}{ }^{2}}{2}=k \frac{\pi d_{\mathrm{j}}^{2}}{4} \rho_{\mathrm{L}} g h_{\mathrm{j}}+\pi d_{\mathrm{j}} \sigma \sin \theta
$$

ここで， $v_{\mathrm{n}}{ }^{\prime}$ は浴表面における噴流中心軸上速度 $[\mathrm{m} / \mathrm{s}], k$ は 調整係数 $[-], g$ は重力加速度 $\left[\mathrm{m} / \mathrm{s}^{2}\right], \sigma$ は表面張力 $[\mathrm{N} / \mathrm{m}]$, $\theta$ は窒みの上端が水平面となす角度 $[\mathrm{deg}$.$] である。静水圧$ は篞み表面の至る所で等しく働くことはないので調整の ための係数 $k$ を導入した。調整係数 $k$ は 0 と 1 の間の值をと る。噴流速度 $v_{\mathrm{n}}{ }^{\prime}$ につては，前述の Kumagai and Iguchiの

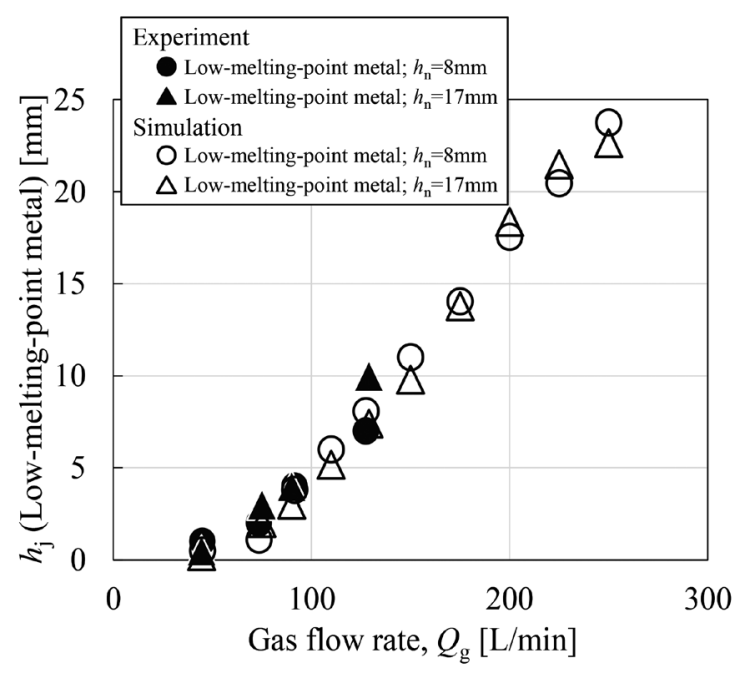

Fig. 7. Cavity depth by experiment and simulation.
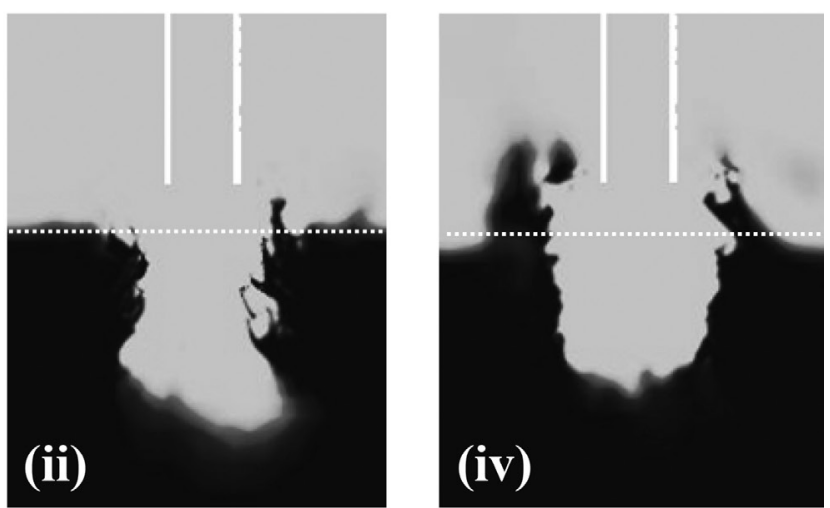

(b) $250 \mathrm{~L} / \mathrm{min}$

Fig. 8. Wave motion on low-melting-point metal bath. 
関係式（1）を用いた。

ステージ Aに拈いて，洼みの周辺はほとんど盛り上がる ことなく水平面に滑らかにつながっているとみなせば，角 度 $\theta$ は十分小さいとみなすことができる。そこで, 表面張

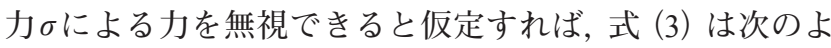
うになる。

$$
\frac{\pi d_{\mathrm{j}}^{2}}{4} \frac{\rho_{\mathrm{g}} v_{\mathrm{n}}{ }^{\prime 2}}{2}=k \frac{\pi d_{\mathrm{j}}^{2}}{4} \rho_{\mathrm{L}} g h_{\mathrm{j}}
$$

上式 $(4)$ から筀みの貫入深さ $h_{\mathrm{j}}$ は次式で与えられる。

$$
\begin{aligned}
& h_{\mathrm{j}}=\frac{\rho_{\mathrm{g}} v_{\mathrm{n}}{ }^{\prime 2}}{2 k \rho_{\mathrm{L}} g}=d_{\mathrm{ni}} \frac{\rho_{\mathrm{g}} v_{\mathrm{n}}{ }^{\prime 2}}{2 k \rho_{\mathrm{L}} g d_{\mathrm{ni}}}=d_{\mathrm{ni}}\left(\frac{4}{\pi}\right)^{2} \frac{\mathrm{Fr}_{\mathrm{m}}{ }^{\prime}}{2 k}=\frac{0.811}{k} d_{\mathrm{ni}} \mathrm{Fr}_{\mathrm{m}}{ }^{\prime} \\
& \mathrm{Fr}_{\mathrm{m}}{ }^{\prime}=\left(\frac{\pi}{4}\right)^{2} \frac{\rho_{\mathrm{g}} v_{\mathrm{n}}{ }^{\prime 2}}{\rho_{\mathrm{L}} g d_{\mathrm{ni}}}
\end{aligned}
$$

ここで, $\mathrm{Fr}_{\mathrm{m}}$ ' は慣性力と浮力の比を表すフルード数の一種 であり, 速度を浴表面に打ける噴流速度 $v_{\mathrm{n}}$ とした時の修正 フルード数と呼ぶことにする。式 (5) は次のように無次元 表示できる。

$$
\frac{h_{\mathrm{j}}}{d_{\mathrm{ni}}}=\frac{0.811}{k} \mathrm{Fr}_{\mathrm{m}}{ }^{\prime}
$$

調整係数 $k$ の值は後で示すように, 実験結果や数值解析結 果と比較することによって決定する。

$5 \cdot 1 \cdot 2$ ステージB

ステージ Bでも式 (7) が近似的に適用できると思われる が, 洼みの周辺が複雑な形状を示し, 表面張力の影響も出 てくる可能性がある。このステージでの貫入深さの整理法 については, 今後実験結果や数值解析結果を蓄積してから 行いたい。

$5 \cdot 1 \cdot 3$ ステージ C

徳田によれば，ステージCでは四つの過程 (i)〜 (iv) が 繰り返される。過程 (i) に示すようにステージBよりも筀 みは深くなり, (ii), (iii) では気柱の先端が気泡のように なる。(iii) のように気柱の入口が狭まると, 噴流が窪み形 成に寄与することなく上方へ跳ね返されるようになる。こ れにより, 浴中の気泡が浮上して浴表面に到達し, 過程 （iv）にて液滴が生じる。このステージCとされる領域では $h_{\mathrm{n}} / d_{\mathrm{ni}}$ の大きい場合に対して多くの実験式が報告されてい る $^{1-6,13-16)}$ 。以下に, 水や溶融金属に対して提案された実験 式についていくつか示す。なお，このようなガス吹き付け による篞み形成挙動の整理に, 以下の式 (8) で定義される 修正フルード数 $\mathrm{Fr}_{\mathrm{m}}$ がよく用いられている。

$$
\mathrm{Fr}_{\mathrm{m}}=\left(\frac{\pi}{4}\right)^{2} \frac{\rho_{\mathrm{g}} v_{\mathrm{n}}^{2}}{\rho_{\mathrm{L}} g d_{\mathrm{ni}}}
$$

先述の式（6）においても修正フルード数を定義したが，式 （6）の修正フルード数は速度を浴表面における噴流速度 $v_{\mathrm{n}}$ ' とした時の修正フルード数であるのに対し, 式 (8) で定義 した修正フルード数は速度をノズル出口における噴流速度 $v_{\mathrm{n}}$ とした時の修正フルード数であることに留意されたい。 浴表面での窪み形成挙動を整理するのには，浴表面におけ る噴流速度を用いた修正フルード数を用いるのが望ましい が, 以下に示す実験式を導出する過程からは浴表面におけ る噴流速度を算出することが困難であるため, 従来の整理 方法であるノズル出口に打ける噴流速度を用いた修正フ ルード数の形で示している。

(1) Tanaka and Okaneの実験式

Tanaka and Okaneは水一空気系に対して次式を提案して いる ${ }^{10)}$ 。

$$
\frac{h_{\mathrm{j}}}{h_{\mathrm{n}}}\left(1+\frac{h_{\mathrm{j}}}{h_{\mathrm{n}}}\right)^{2}=\frac{15.2^{2}}{2 \pi} \frac{\dot{p}}{\rho_{\mathrm{L}} g h_{\mathrm{n}}{ }^{3}}=\frac{15.2^{2}}{2 \pi} \mathrm{M}_{\mathrm{m}}
$$

ここで, $\dot{p}$ はランス出口におけるガスの運動量, $\mathrm{M}_{\mathrm{m}}$ は運動 量数 $[$ 一] であり，それぞれ次式で与えられる。

$$
\begin{aligned}
& \dot{p}=\dot{m}_{\mathrm{g}} v_{\mathrm{n}}=\rho_{\mathrm{g}} Q_{\mathrm{g}} v_{\mathrm{n}}=\rho_{\mathrm{g}} \frac{\pi d_{\mathrm{ni}}{ }^{2}}{4} v_{\mathrm{n}}{ }^{2} \\
& \mathrm{M}_{\mathrm{m}}=\frac{\dot{p}}{\rho_{\mathrm{L}} g h_{\mathrm{n}}^{3}}=\frac{\pi}{4} \frac{\rho_{\mathrm{g}} d_{\mathrm{ni}}{ }^{2} v_{\mathrm{n}}{ }^{2}}{\rho_{\mathrm{L}} g h_{\mathrm{n}}{ }^{3}}=\frac{\pi}{4}\left(\frac{d_{\mathrm{ni}}}{h_{\mathrm{n}}}\right)^{3} \frac{\rho_{\mathrm{g}} v_{\mathrm{n}}{ }^{2}}{\rho_{\mathrm{L}} g d_{\mathrm{ni}}}=\frac{4}{\pi}\left(\frac{d_{\mathrm{ni}}}{h_{\mathrm{n}}}\right)^{3} \mathrm{Fr}_{\mathrm{m}}
\end{aligned}
$$

式 (10)，(11）を用いると, 式 (9) は次式のように変形でき る。

$$
\frac{h_{\mathrm{j}}}{h_{\mathrm{n}}}\left(1+\frac{h_{\mathrm{j}}}{h_{\mathrm{n}}}\right)^{2}=46.8\left(\frac{d_{\mathrm{ni}}}{h_{\mathrm{n}}}\right)^{3} \mathrm{Fr}_{\mathrm{m}}
$$

この式の成立範囲は, $\mathrm{M}_{\mathrm{m}}=0.002 \sim 0.25$ であるが，水一空 気系の本測定值は, $\mathrm{M}_{\mathrm{m}}=0.112 \sim 9.18$ 範囲で得られてい る。したがって, 水一空気系の本測定值のうち $\mathrm{M}_{\mathrm{m}}$ の小さ い所，すなわち臨界修正フルード数 0.911 の近傍の測定值 は式 (12) とかろうじて比較可能である。

(2) Ishikawa らの式

Ishikawa らは水一窒素系の貫入深さ $h_{\mathrm{j}}$ に対して次式を提 案している5

$$
\frac{h_{\mathrm{j}}}{d_{\mathrm{ni}}}=\frac{h_{\mathrm{j} 0}}{d_{\mathrm{ni}}} \exp \left[-1.77 \frac{h_{\mathrm{n}}}{h_{\mathrm{j} 0}}\right] .
$$

ここで, $h_{\mathrm{j} 0}$ はランス高さをゼロ $\left(h_{\mathrm{n}}=0\right)$ とした際の窪み深 さである。また, 式 (13) 中のいくつか無次元量を本論文の 記号に直すと， 


$$
\begin{aligned}
\frac{h_{\mathrm{j} 0}}{d_{\mathrm{ni}}} & =0.426\left(\frac{Q_{\mathrm{g}}}{d_{\mathrm{ni}}{ }^{2} \sqrt{g d_{\mathrm{ni}}}}\right)^{2 / 3} \\
& =0.426\left(\frac{\pi}{4}\right)^{-2 / 3}\left(\frac{\pi^{2} \rho_{\mathrm{L}}}{16 \rho_{\mathrm{g}}}\right)^{1 / 3}\left\{\left(\frac{\pi}{4}\right)^{2} \frac{\left.\rho_{\mathrm{g}} v_{\mathrm{n}}{ }^{2}\right\}_{\mathrm{L}} g d_{\mathrm{ni}}}{1 / 3}=4.04 \mathrm{Fr}_{\mathrm{m}}{ }^{1 / 3}\right.
\end{aligned}
$$

$$
\frac{h_{\mathrm{n}}}{h_{\mathrm{j} 0}}=\frac{h_{\mathrm{n}}}{4.04 d_{\mathrm{ni}} \mathrm{Fr}_{\mathrm{m}}^{1 / 3}}
$$

となる。ただし，上式の変形過程において，液体と気体の 密度には, 本実験での水と空気の值を与えた。式(14)，(15) を式 (13) に代入すると次式が得られる。

$$
\frac{h_{\mathrm{j}}}{d_{\mathrm{ni}}}=4.04 \mathrm{Fr}_{\mathrm{m}}{ }^{1 / 3} \exp \left[-0.438 \frac{h_{\mathrm{n}}}{d_{\mathrm{ni}}} \mathrm{Fr}_{\mathrm{m}}{ }^{-1 / 3}\right]
$$

式（16）の成立範囲は, $h_{\mathrm{n}} / h_{\mathrm{j} 0}=0.03 \sim 0.65, h_{\mathrm{n}} / d_{\mathrm{ni}}=0 \sim 100$ であり, 本研究の範囲は, $h_{\mathrm{n}} / h_{\mathrm{j} 0}=0.133 \sim 0.682, h_{\mathrm{n}} / d_{\mathrm{ni}}=0.8$ 〜 1.7 となり, 式 (16) を水一空気系の本実験結果と比較す ることは可能である。

(3) Kumagai and Iguchiの式

Kumagai and Iguchi ${ }^{25)}$ はつぎの実験式を提案している。

$$
\frac{h_{\mathrm{j}}}{d_{\mathrm{ni}}}=4.1 \mathrm{Fr}_{\mathrm{m}}{ }^{1 / 3} \quad\left(\mathrm{Fr}_{\mathrm{m}}{ }^{\prime} \geq 2, h_{\mathrm{n}} / d_{\mathrm{ni}} \leq 20\right)
$$

本研究の範囲は, $\mathrm{Fr}_{\mathrm{m}}{ }^{\prime}=0.07 \sim 5.7$ であり, $\mathrm{Fr}_{\mathrm{m}}{ }^{\prime} \geqq 2$ の範囲で 比較可能である。ただし, 式 (17) の $\mathrm{Fr}_{\mathrm{m}}{ }^{\prime}$ の適用範囲の上限 については分かっていない。

(4) Koria and Langeの式 (溶鉄一酸素系)

前述のように, 溶鉄一酸素系の貫入深さについてはラン ス位置の高い場合 $\left(h_{\mathrm{n}} / d_{\mathrm{ni}}>10\right)$ を対象として多くの研究が 行われている ${ }^{13-16)}$ 。Koria and Langeはそれらの結果をまと めて次式を提案した ${ }^{16)}$ 。

$$
\begin{aligned}
& \frac{h_{\mathrm{j}}}{h_{\mathrm{n}}}=4.469 \mathrm{M}_{\mathrm{m}} \\
& \mathrm{M}_{\mathrm{m}}=\frac{\dot{p}}{\rho_{\mathrm{L}} g h_{\mathrm{n}}{ }^{3}}=\frac{\pi}{4} d_{\mathrm{ni}}{ }^{2} \frac{1.27\left(p_{0}-p_{\mathrm{a}}\right)}{\rho_{\mathrm{L}} g h_{\mathrm{n}}{ }^{3}}
\end{aligned}
$$

ここで, $p_{0}$ は高圧酸素ガス供給容器内の圧力 $[\mathrm{Pa}], p_{\mathrm{a}}$ は大 気圧 $[\mathrm{Pa}]$ である。式 (18) の運動量数 $\mathrm{M}_{\mathrm{m}}$ の指数が 0.66 で あり，2/3に近いことから，ステージ B近傍で適用できるも のと思われるが，この点の詳細については，前述のように 実験結果や数值解析結果が不足していることから今後の検 討課題としたい。

以上のことをまとめると, 貫入深さ $h_{\mathrm{j}}$ は修正フルード数 $\mathrm{Fr}_{\mathrm{m}}{ }^{\prime}$ の増加につれて, すなわちステージ Aから Cへと移つ
ていくにつれて $\mathrm{Fr}_{\mathrm{m}}{ }^{\prime}$ の1乗から 1/3 乗へと変化していくと 推察できる。

\section{$5 \cdot 2$ ステージCの下限境界に関する考察}

ステージCの過程（iii）では，気柱の先端がくびれて気 泡のようになっている。このことは, 気泡巻き込み現象の 起こる臨界ガス流量, あるいは臨界速度を求めれば, おお よそではあるが，ステージCとされる領域で提案された式 （17）の成立する範囲の下限を予測できることを示唆して いる。なお，式（7）の成立範囲は臨界速度よりも十分小さ い所にある。

周知のように，連続鋳造鋳型内ではモールドパウダー の巻き込みによる品質の劣化が積年の課題であり，その 原因となる巻き込及機構について多くの研究が行われて きた ${ }^{26-31)}$ 。今までに多数の巻き込み機構が報告されている が，まだ定説はない。最も古くから提唱されている機構の 一つに次のようなものがある。浸漬ノズルの出口から鋳型 内に入った溶鋼が鋳型の側壁に衝突して浸漬ノズル側へ 跳ね返り，モールドパウダー層に接触するとモールドパウ ダーと溶鋼の界面には強いせん断応力が働く。溶鋼の速度 がある臨界值 $V_{\mathrm{cr}}$ を超えると，モールドパウダーが滴となっ て溶鋼中に取り込まれる。これを定常反転流によるモール ドパウダー巻き込みと呼ぶことにする。臨界速度 $V_{\mathrm{cr}}$ を求 めるに際し, 浅井はモールドパウダー層から球状のモール ドパウダー滴を引き出すに要する仕事に着目し, 臨界速度 に対して次式を提案した ${ }^{311}$ 。

$$
V_{\mathrm{cr}}=\left[48 \frac{g\left(\rho_{\mathrm{L}}-\rho_{\mathrm{S}}\right) \sigma_{\mathrm{SL}}}{\rho_{\mathrm{S}}^{2}}\right]^{1 / 4}
$$

ここで, $\rho_{\mathrm{S}}$ はモールドパウダーの密度， $\sigma_{\mathrm{SL}}$ は界面張力であ る。

浴表面に吹き付けた空気が気泡となって液体中に巻き込 まれる現象は，上記モールドパウダー巻き込み現象に類似 している。そこで, $V_{\mathrm{cr}}, \rho_{\mathrm{S}}, \sigma_{\mathrm{SL}}$ を本論文の記号 $v_{\mathrm{ncr}}, \rho_{\mathrm{g}}, \sigma$ に 置き換え, 液体が水と低融点金属, 気体が空気の場合につ いて $v_{\text {ncr }}$ を計算するとつぎのようになる。

(1) 水一空気系

$$
\begin{aligned}
v_{\mathrm{ncr}}^{\prime} & =\left[48 \frac{g\left(\rho_{\mathrm{L}}-\rho_{\mathrm{g}}\right) \sigma}{\rho_{\mathrm{g}}{ }^{2}}\right]^{1 / 4} \\
& =\left[48 \frac{9.8(997-1.17) \times 0.073}{1.17^{2}}\right]^{1 / 4}=12.6\left[\frac{\mathrm{m}}{\mathrm{s}}\right]
\end{aligned}
$$

（2）低融点金属一空気系

$$
v_{\text {ncr }}^{\prime}=\left[48 \frac{9.8(9473-1.17) \times 0.431}{1.17^{2}}\right]^{1 / 4}=34.4\left[\frac{\mathrm{m}}{\mathrm{s}}\right]
$$


低融点金属一空気系の臨界速度の方が水一空気系の值より も3倍ほど大きいことが分かる。

本実験条件下のランス出口速度は前述のように $v_{\mathrm{n}}=9.46$ $\sim 27.4 \mathrm{~m} / \mathrm{s}$ である。また $h_{\mathrm{n}} / d_{\mathrm{ni}}=0.8,1.7$ であるから, 式 (1) から判断して， $v_{\mathrm{n}}{ }^{\prime}$ は $v_{\mathrm{n}}$ にほぼ等しいと拈り。水一空気系 の臨界速度は $v_{\mathrm{ncr}}{ }^{\prime}=12.6 \mathrm{~m} / \mathrm{s}$ であり, $v_{\mathrm{n}}{ }^{\prime}>12.6 \mathrm{~m} / \mathrm{s}$ における 水一空気系の貫入深さ $h_{\mathrm{j}}$ の測定值は式 (12)，(17) などの ように $\mathrm{Fr}_{\mathrm{m}}{ }^{\prime}$ の $1 / 3$ 乗で近似できる可能性がある。一方, 低融 点金属一空気系の臨界速度 $v_{\mathrm{ncr}}{ }^{\prime}$ は $34.4 \mathrm{~m} / \mathrm{s}$ であり，ガス流 量 $Q_{\mathrm{g}}<162.1 / \mathrm{min}$ では式 (7) で, それ以上では $\mathrm{Fr}_{\mathrm{m}}{ }^{\prime}$ の 1/3 乗 で近似できると考えられる。

なお, 本研究で対象としている流れ場への式 (20) の適 用性について少し言及する。浅井は, 球形のモールドパウ ダー滴が溶鋼とモールドパウダーの界面を通過するとき に，モールドパウダー滴の有する慣性力による仕事がモー ルドパウダー滴に働く浮力による仕事と表面張力による 仕事の和よりも大きければ，モールドパウダー滴は溶鋼中 に巻き込まれると考え，滴の直径が実数解を持つという条 件から臨界流速に対する式 (20) を導いている。モールド パウダーを空気に，溶鋼を水やウッドメタルに置き換えれ ば，いずれも流体であることから同じことが言えると考 え, 本研究では式 (20) を適用した。ただし, 本研究の場合, 気体は液体よりも変形しやすく, 気泡の径にもよるが球形 の気泡が巻き込まれるとは考えにくい。また，空気流速が 大きければ粘性散逸も考慮する必要があるのと予想され る。したがって，式（20）はあくまでも近似式であって，詳 細については今後の検討が必要である。

\section{$5 \cdot 3$ 予測式での整理}

$5 \cdot 3 \cdot 1$ 水一空気系

Fig.9, 10 に各ランス高さでの水一空気系の無次元窪み深 さ $h_{\mathrm{j}} / d_{\mathrm{ni}}$ の測定值と数值計算值を修正フルード数 $\mathrm{Fr}_{\mathrm{m}}{ }^{\prime}$ に対し て示す。な推, 他の研究者によって提案されている水一空
気系の予測式 (12)，(16)，(17）もそれぞれの適用範囲に応 じて示した。それらの式は $\mathrm{Fr}_{\mathrm{m}}{ }^{\prime}$ ではなく $\mathrm{Fr}_{\mathrm{m}}$ の関数として 表されているものもあるが, 本実験の範囲ではランス位置 が浴表面に近い $\left(h_{\mathrm{n}} / d_{\mathrm{ni}}=0.8,1.7\right)$ ことから, 式 (1) から判 断して， $v_{\mathrm{n}}{ }^{\prime}$ は $v_{\mathrm{n}}$ にほぼ等しいとおける。つまり， $v_{\mathrm{n}}=v_{\mathrm{n}}$ 'と なるので, $\mathrm{Fr}_{\mathrm{m}}{ }^{\prime}=\mathrm{Fr}_{\mathrm{m}}$ とおける。

四より，ランス高さが大きい場合には従来の予測式は比 較的良い一致を示すが，ランス高さが小さい場合には大幅

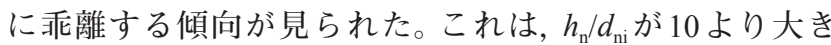
な領域で提案された式であるため，特にランス高さが小さ い場合には適用することが困難であると示している。そこ で, $h_{\mathrm{n}} / d_{\mathrm{ni}}<10$ の領域に拈ける貫入深さの推定式を検討し た。水一空気系の臨界速度を与える式 (21) の $12.6 \mathrm{~m} / \mathrm{s}$ を用 いて修正フルード数の臨界值を求めると $\mathrm{Fr}_{\mathrm{mc}}{ }^{\prime}=1.17$ とな る。本報での実験および解析条件では, 臨界值以下は3 水 準であるが, $\mathrm{Fr}_{\mathrm{m}}$ 'に対し直線的に増加していることがわか る。つまり, 先述のように流速 $v_{\mathrm{n}}{ }^{\prime}$ の二乗に比例していると いうことを意味している。実験での測定值と数值解析結果 の両方に対し最小二乗法を適用すると, ステージ A での貫 入深さは以下の式 (23) にて表すことができる。

$$
\frac{h_{j}}{d_{n i}}=1.3 \mathrm{Fr}_{\mathrm{m}}{ }^{\prime}
$$

このときの調整係数は, 式 (7) より $k=0.624$ となる。Fig.3 のステージ Aの模式四から考えて, 1 よりも小さい $k$ の值 は妥当であるが, データが不足しているためこの值と断定 することはできない。

一方, 臨界值以上の領域に関しては, 修正フルード数 $\mathrm{Fr}_{\mathrm{m}}{ }^{\prime}$ が 2 6の範囲では既存の推定式とはやや乘離が見られ る。そこで，これらの範囲においても適用できる推定式と して，最小二乗法にて以下の式（24）を提案する。

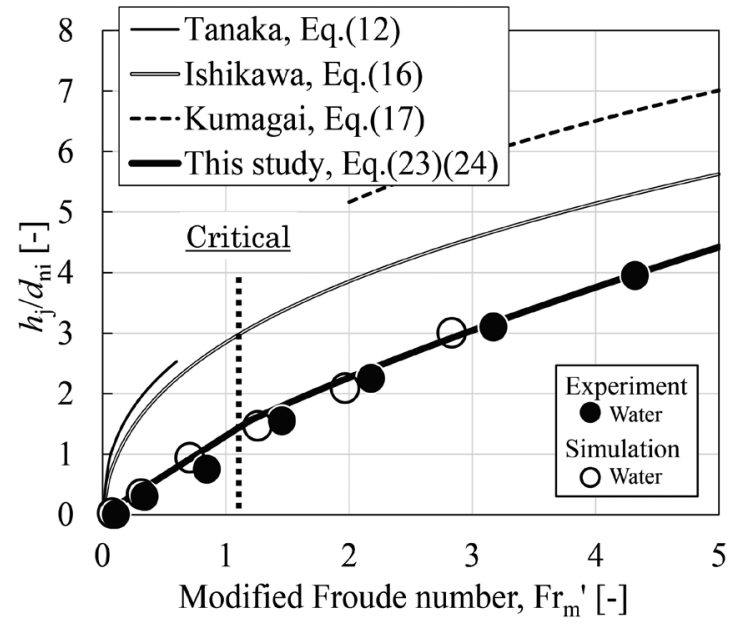

Fig. 9. Dimensionless cavity depth by modified Froude number (Water, $h_{\mathrm{n}}=8 \mathrm{~mm}$ ).

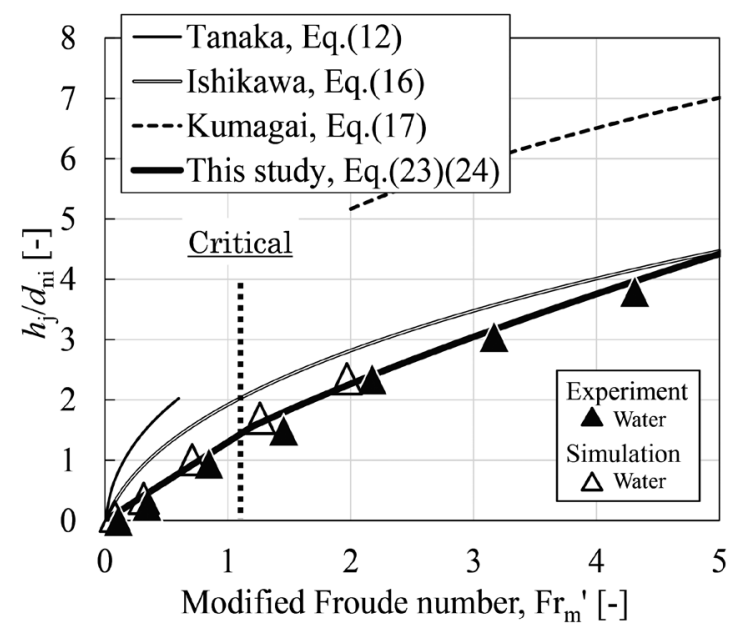

Fig. 10. Dimensionless cavity depth by modified Froude number (Water, $h_{\mathrm{n}}=17 \mathrm{~mm}$ ). 


$$
\frac{h_{j}}{d_{n i}}=1.37 \mathrm{Fr}_{\mathrm{m}}^{0.73}
$$

以上のように，水の場合には臨界值に対して式 (21) が 近似的に適用でき, 修正フルード数の臨界值 $\mathrm{Fr}_{\mathrm{mc}}{ }^{\prime}=1.17$ よ り小さいときには $\mathrm{Fr}_{\mathrm{m}}{ }^{\prime}$ の1乗で, 臨界值よりも大きいとき には $\mathrm{Fr}_{\mathrm{m}}{ }^{\prime}$ の0.73乗で近似できることがわかった。先に述べ たように $\mathrm{Fr}_{\mathrm{m}}{ }^{\prime}$ の1/3乗では近似できなかったが，これはラ ンスが浴面に近い $h_{\mathrm{n}} / d_{\mathrm{ni}}$ が $10 よ り も 十$ 分小さい (Near field) ためである。臨界值よりも大きいときには $\mathrm{Fr}_{\mathrm{m}}{ }^{\prime}$ の 0.73 乗で 近似できることから，さらに $\mathrm{Fr}_{\mathrm{m}}{ }^{\prime}$ が大きい条件では $1 / 3$ 乗 に近づくと推測されるが，これら条件に関しては今後の検 討課題としたい。

\section{$5 \cdot 3 \cdot 2$ 低融点金属一空気系}

Fig.11，12に各ランス高さでの低融点金属一空気系の無 次元等み深さ $h_{\mathrm{j}} / d_{\mathrm{ni}}$ の測定值と数值計算值を修正フルード 数 $\mathrm{Fr}_{\mathrm{m}}$ 'に対して示す。こちらも同様に，他の研究者によっ て提案されている推定式をそれぞれの適用範囲に応じて示

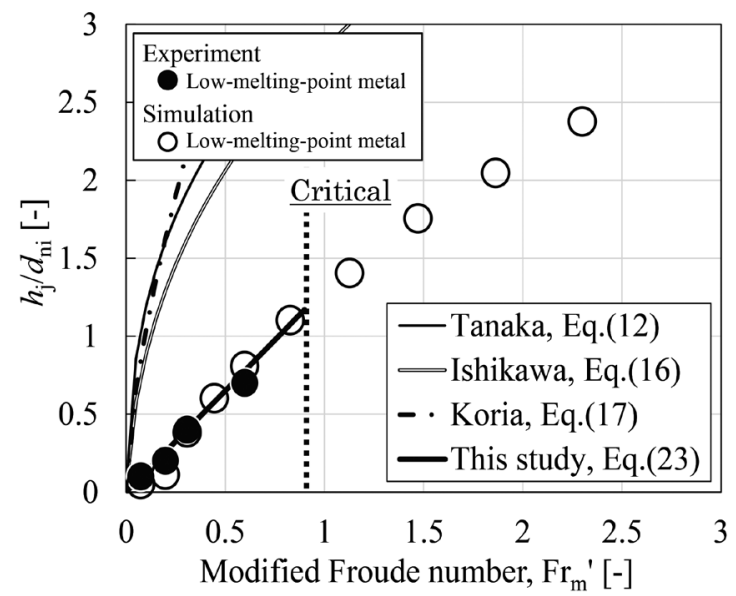

Fig. 11. Dimensionless cavity depth by modified Froude number (Low-melting-point metal, $h_{\mathrm{n}}=8 \mathrm{~mm}$ ).

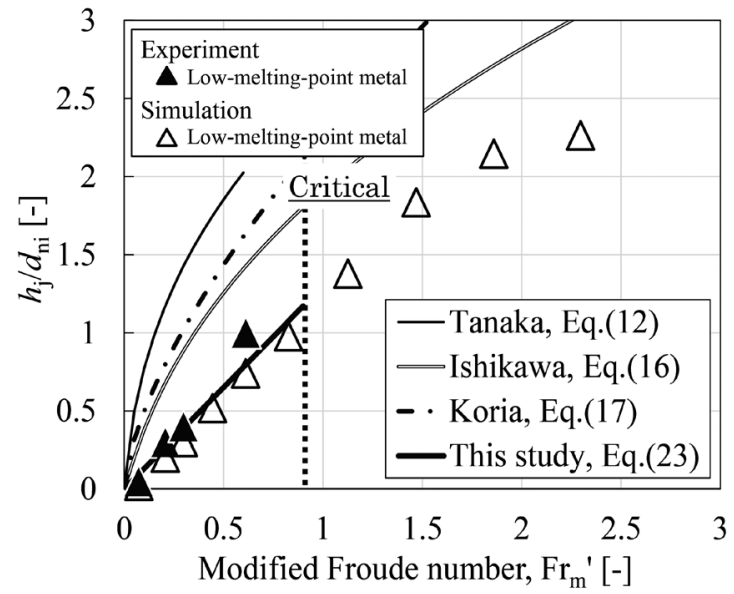

Fig. 12. Dimensionless cavity depth by modified Froude number (Low-melting-point metal, $h_{\mathrm{n}}=17 \mathrm{~mm}$ ).
している。罒より, 従来の推定式とは大幅に異なっている ことがわかる。これは, $h_{\mathrm{n}} / d_{\mathrm{ni}}$ が 10 より大きな領域で提案さ れた式であるため，今回のような条件では適用することが 困難であると示している。そこで, $h_{\mathrm{n}} / d_{\mathrm{ni}}<10$ の領域におけ る貫入深さの推定式を検討した。

低融点金属一空気系の臨界速度を与える式 (22) の $34.4 \mathrm{~m} / \mathrm{s}$ を用いて修正フルード数の臨界值を求めると $\mathrm{Fr}_{\mathrm{mc}}$, $=0.911$ となる。実験での測定值はすべて臨界修正フルー ド数よりも小さいところに存在しているが, $\mathrm{Fr}_{\mathrm{m}}{ }^{\prime}$ に対して 直線的に増加しており，式（7）の関数形が適用できる。そ こで, 実験での測定值と数值解析結果の両方に対し最小二 乗法を用いて近似すると, 水浴で得られた式 (23) で整理 できることがわかった。

数值解析についても, 修正フルード数の臨界值 0.911 よ りも小さいところにある低融点金属一空気系の数值計算結 果は測定值にほぼ一致しており，式 (23) で近似できる。一 方, 臨界值より大きい範囲においても, 検証が必要だが式 （24）を適用したところ, 計算結果と式 (24) との一致は比 較的良いことがわかった。しかし，修正フルード数が $\mathrm{Fr}_{\mathrm{m}}{ }^{2}$ $>>0.911$ の領域における数值計算については, 測定值が 無いので㛜密な議論はできない。今後の課題としたい。

以上のことから, 表面張力が約 6 倍異なる低融点金属一 空気系においても，今後の検証は必要ではあるものの同じ 予測式を用いて貫入深さを予測することが可能である。す なわち, 窪みの貫入深さに関しては, 今回調査した物性值 の範囲内では表面張力の影響が小さいといえる。

\section{6. 結言}

本報告では, 水と低融点金属を用いたコールドモデル実 験に基づき，上吹きランスからのガス噴流による自由界面 挙動に及ぼす液体の物性值の影響をランス出口と浴表面が 近い場合 $\left(h_{\mathrm{n}} / d_{\mathrm{ni}}=0.8,1.7\right)$ について調査した。得られた成 果は以下のようにまとめられる。

（1）上吹きランスからのガス噴流によって液面近傍に誘起 される窪みの挙動を調査し, 低流量では徳田が示した ステージ Aが, 高流量ではステージ Cが発生すること を数值解析にて再現した。

（2）水一空気系の窪みの貫入深さに関し，下記の式 (23) と （24）を提案した。

$$
\begin{aligned}
& \frac{h_{j}}{d_{n i}}=1.3 \mathrm{Fr}_{\mathrm{m}}{ }^{\prime} \quad\left(0.8 \leqq h_{\mathrm{n}} / d_{\mathrm{ni}} \leqq 1.7, \mathrm{Fr}_{\mathrm{mc}}{ }^{\prime}<1.17\right) \ldots \ldots \ldots \ldots \ldots . . . . . . . \\
& \frac{h_{j}}{d_{n i}}=1.37 \mathrm{Fr}_{\mathrm{m}}^{\prime 0.73}\left(0.8 \leqq h_{\mathrm{n}} / d_{\mathrm{ni}} \leqq 1.7,1.17 \leqq \mathrm{Fr}_{\mathrm{mc}}{ }^{\prime}<5.5\right) \cdots
\end{aligned}
$$

（3）低融点金属一空気系の窪みの貫入深さに関し, 臨界速 度以下の領域では, 水一空気系の窪みの貫入深さの式 (23) で整理できることがわかった。 


\section{文献}

1 ) R.D.Collins and H.Lubanska: Br. J. Appl. Phys., 5(1954), 22.

2 ) K.Segawa, S.Maehara, M.Shimada and M.Ishibashi: Tetsu-toHagané, 44(1958), 1056.

3 ) M.Shimada, M.Ishibashi, T.Ariyoshi and H.Morise: Tetsu-to-Hagané, 52(1966), 1499.

4 ) E.T.Turkdogan: Chem. Eng. Sci., 21(1966), 1133.

5 ) H.Ishikawa, S.Mizoguchi and K.Segawa: Tetsu-to-Hagané, 58(1972), 76.

6 ) S.Ito and I.Muchi: Tetsu-to-Hagané, 55(1969), 1164.

7 ) J.Szekely and N.J.Themelis: Rate Phenomena in Process Metallurgy, John Wiley \& Sons Inc., New York, (1971).

8 ) A.Masui, W.Wenzel and F.R.Block: Tetsu-to-Hagané, 57(1971), S404.

9 ) M.Mori, I.Kobayashi, T.Nakajima, T.Ogino and G.Yoshida: Tetsu-toHagané, 70(1984), S244.

10) T.Tanaka and K.Okane: Tetsu-to-Hagané, 74(1988), 1593.

11) S.Kitamura and K.Okohira: Tetsu-to-Hagané, 76(1990), 199.

12) Y.Nakao, T.Ono, M.Mimura, Y.Takeda, H.Horiuchi and T.Oura: Tetsu-to-Hagané, 68(1982), S14.

13) J.Maatsch: Techn. Mitt. Krups Forsch-Ber., 20(1962), 1.

14) R.A.Flinn, R.D.Pehlke, D.R.Glass and O.Hays: Trans. Metall. Soc. AIME, 239(1967), 1776.

15) S.C.Koria and K.W.Lange: Arch. Eisenhüttenwes., 55(1984), 427.

16) S.C.Koria and K.W.Lange: Steel Res., 58(1987), 421.

17) N.Asahara, K.Naito, I.Kitagawa, M.Matsuo, M.Kumakura and M.Iwasaki: Steel Res. Int., 82(2011), 587.
18) X.Zhou, M.Ersson, L.Zhong, J.Yu and P.Jönsson: Steel Res. Int., 85(2014), 273.

19) M.Ando, D.Komagata, K.Takahashi, T.Ishii and K.Ueno: Tetsu-toHagané, 101(2015), 82.

20) H.J.Odenthal, W.H.Emling, J.Kempken and J.Schlüter: Iron Steel Technol., 4-11(2007), 71.

21) Q.Li, M.Li, S.Kuang and Z.Zou: Metall. Mater. Trans. B, 46(2015), 1494.

22) M.Iguchi and H.Tokunaga: Metall. Mater. Trans. B, 33(2002), 695.

23) 徳田昌則 : 第 $100 \cdot 101$ 回西山記念技術講座, 日本鉄鋼協会, 東京, (1984), 41.

24) V.B.Okhotckii: Izv. VUZ. Cher. Met., 1(1984), 45.

25) T.Kumagai and M.Iguchi: ISIJ Int., 41(2001), S52.

26) D.Gupta and A.K.Lahiri: Metall. Mater. Trans. B, 25(1994), 227.

27) M.Iguchi, J.Yoshida, T.Shimizu and Y.Mizuno: ISIJ Int., 40(2000), 685.

28) H.Tanaka, H.Kuwatori and R.Nishihara: Tetsu-to-Hagané, 78(1992), 761.

29) Z.Wang, K.Mukai, Z.Ma, M.Nishi, H.Tsukamoto and F.Shi: ISIJ Int., 39(1999), 795.

30) J.Yoshida, M.Iguchi and S.Yokoya: Tetsu-to-Hagané, 87(2001), 529.

31) 浅井滋生：第 $100 \cdot 101$ 回西山記念技術講座，日本鉄鋼協会, 東京, (1984), 90 .

32) C.W.Hirt and B.D.Nichols: J. Comput. Phys., 39(1981), 201.

33) T.H.Shih, W.W.Liou, A.Shabbir, Z.Yang and J.Zhu: Comput. Fluids, 24(1995), 227 